\title{
Profile of Pro-social Behavior and The Implication of Guidance and Counseling
}

\author{
Yusi Riksa Yustiana \\ Department of Educational Psychology and Guidance \\ Universitas Pendidikan Indonesia, Indonesia \\ yusiriksa@upi.edu
}

\author{
Handita Widhi Atma \\ Department of Educational Psychology and Guidance \\ Universitas Pendidikan Indonesia, Indonesia \\ atmahandita@upi.edu
}

\author{
M. Solehuddin \\ Department of Educational Psychology and Guidance \\ Universitas Pendidikan Indonesia, Indonesia \\ msolehuddin@upi.edu
}

\begin{abstract}
The aim of this study is to describe the pro-social behavior of high grade elementary school students and the implications of guidance and counseling services. The study uses a quantitative approach with descriptive methods. The research subjects totaled 65 students as sample saturated. The research instrument used the scale of students' pro-social behavior. Data analysis was performed by calculating the average and standard deviation, so that the categorization was obtained. The results showed that pro-social behavior of children was in the high category owned by $50.67 \%$ of students. Achievement of aspects of cooperative behavior is $70 \%$, helping behavior is $80 \%$ and problem solving behavior is $63 \%$. pro-social Increased pro-social behavior that occurs in students in the low category. Some high-level students are ready to face the skills needed in the distracting 4.0 era, while others are not ready, guidance and counseling services in the social field are needed to develop competency in pro-social behavior.
\end{abstract}

Keywords: pro-social behavior, high grade elementary school students, collaborative guidance

\section{INTRODUCTION}

Humans are highly social creatures with the ability to develop strong emotional connections before an early age and continue to develop with deep involvement with others and the environment throughout life. pro-social behavior is behavior that provides benefits for oneself and others. pro-social behavior is a human action that encourages social cohesion by benefiting social partners (Cirelli, 2018). The tendency of pro-social attitudes in humans has been shown since infancy (Eisenberg, 1982, Ross, 2017, Cirelli, 2018, Hammond, 2017, Enesco.C.S, et al, 2013). Social behavior competence is important to be owned by children from an early age, so that children can have social welfare that is pro-social tendencies and functioning well in society.

The development of pro-social behavior in children is divided into three stages (Santrock, 1978). The first stage in the first three years of life of a child pro-social behavior carried out on the grounds of empathy. prosocial behavior is carried out by children on the grounds that it is part of a ritual game or imitation of the behavior of people around them. The second group is four years old children. pro-social behavior in the second group is based on a combination of empathic awareness and adult encouragement that results in a sense of obligation to children to show pro-social behavior. The third group is the age of elementary school children. Throughout elementary school age children begin to learn to express more complex ideas about justice to distribute goods and resolve conflicts.

Hurlock (2011) divides children's social behavior patterns into two groups: social behavior and non-social behavior. Behavioral patterns included in social behavior in children are; imitate, competition, cooperation, sympathy, empathy, social support, sharing, and familiar behavior. Santrok child development figure (1978), explains pro-social behavior as a result of positive moral learning. pro-social behavior is not only positive moral behavior but behavior that is intended to benefit others. pro-social behavior in children manifests in the behavior of giving, sharing, being grateful, and forgiving. The opposite of pro-social behavior Santrock (1978) defines anti-social behavior. Antisocial behavior is behavior that damages or disturbs oneself and / or others. Examples of antisocial behavior in children are skipping class, bullying, and acting not in accordance with environmental regulations. Antisocial behavior occurs in the environment. Hurlock (2011) explains antisocial behavior as non-social behavior is behavior that shows negative, aggression, powerful behavior, self-thinking, selfish, destructive, sex antagonism, and prejudice.

Pro-social behavior is important to be mastered by children because at the child stage the opportunity to establish relationships and interact more broadly not only with family but also with peers and teachers at school. Early experiences of children interacting with the environment outside the home so children need to be equipped with pro-social behavior skills. Hurlock (2011) explains the importance of children's early social experiences outside the home. Unpleasant experiences will give rise to individuality and develop non-social traits that hinder development. Children who develop social behavior well are able to build relationships and play with their peers.

The urgency of mastering pro-social behavior in late age children is a provision for entering adolescence. The transition period of children and adults who experience turmoil and problems caused by rapid physical and psychological changes. Susanto (2015) explains social behavior or pro-social behavior are activities that relate to 
others, activities related to other parties that require socialization in behavior that can be accepted by others, learn to play social roles that can be accepted by others, and efforts develop social attitudes that are worthy of acceptance by others

The importance of developing pro-social behavior in children apart from being the responsibility of parents is also the responsibility of teachers and counselors at school. Hoffman (Susanto, 2015) states that the treatment of parents in childcare determines the child will behave in a pro-social or antisocial manner. When a child starts out of the family environment and enters into peer relationships the influence of pro-social behavior shifts to peers. Ahman (1998) states the process of learning in peer groups is a real social learning, namely by interacting directly while developing skills in social behavior. Development of child pro-social behavior can be done at school. The school is a place where children spend a lot of time learning and socializing with peers, teachers and school staff.

\section{METHOD}

\section{Research Design}

The study used a qualitative approach with descriptive methods to describe the pro-social profile of pro-social high school students. The profile obtained is the rationale for the implications of the guidance and counseling services needed so that high grade elementary school students have high social behavior competencies so that they can be socially prosperous.

\section{Research Subject}

The selection of research subjects is done through an approach to groups that met the required characteristics in accordance with the research topic and personal contacts. The accurate selection of subjects needs to meet the characteristics and experience requirements that are appropriate to the phenomenon under study. The subjects were 5th grade elementary school students SDN 2 Lembang Year 2018/2019.

\section{Data Collection Methods}

The method of data collection is indirectly using the pro-social Behavior Scale instrument. The type of instrument used in research is a scale with self report data collection methods. The selection of self report method with consideration of high grade elementary school children has been able. fill in the scale instrument for measuring pro-social behavior.

The scale is used to measure the pro-social attributes of late-age children on a series of scales from high to low. Specifically developed by Handita Widhi Atma (2019) with a reliability of 0.762 or an acceptable level of reliability. The validity of the instrument was high both internal validity and external validity and passed the legibility test.

\section{Data Analysis Technique}

The data analysis technique used in this research was the centralized trend analysis (average), standard deviation and percentage of achievement calculated using the SPPS instrument.

\section{Validation Method}

Data validation was used triangulation with confirmation through interviews with grade 5 teachers, non-pro-social behavior problems that occurred and children's responses to daily pro-social behavior.

\section{RESULT AND DISCUSSION \\ Profile of Student Pro-Social Behavior}

The research instrument was given to fifth grade students as research samples. Grade 5 students consisted of 65 students who were divided into two classes, namely classes A and B. The results of the data analysis explained the average pro-social assessment score data was 77.6. Compared with the ideal average score of 63, the average student score is higher 14.6. Analysis and categorization of students' pro-social behavior scores in full is presented in Table 1.

Table 1

Frequency Distribution of Student pro-social Behavior

\begin{tabular}{|l|c|c|c|}
\hline \multicolumn{1}{|c|}{ Category } & Range & Frequency & Percentage \\
\hline Low & $21-48$ & 2 & $5,71 \%$ \\
\hline Medium & $49-76$ & 30 & $46,15 \%$ \\
\hline High & $77-105$ & 33 & $50,76 \%$ \\
\hline
\end{tabular}

The results of the analysis carried out on students of class V-A and V-B students were divided into two categories, namely high and medium. The number of students in the high category is higher than students in the low category. Based on the results of the data, services are still needed to improve students' pro-social behavior because there are still students in the moderate category. pro-social behavior of high category students means students have and are able to show pro-social behavior in daily life that is characterized by students being able to perform cooperative behavior in groups, solve problems in groups and provide assistance in group activities.

Pro-social behavior of moderate category students means students have not been able to show pro-social behavior that is shown by the ability to show cooperative behavior in groups, students are able to provide assistance in groups, but students have not been able to solve problems in groups. Low category pro-social behavior means students have not been able to show pro-social behavior in daily life which is shown by not showing cooperative behavior, unable to solve group problems and not providing assistance in group activities.

\section{Overview of Student Pro-Social Behavior Based on Indicators}

Pro-social behavior profile analysis specifically performed on pro-social behavior indicators. pro-social behavior indicators consist of cooperative behavior, helpful behavior and problem solving. Achieving the highest behavior in the aspect of behavior helps $80 \%$ are in the high category. High category helping behavior means that students provide assistance to others in their daily lives as indicated by providing physical and psychological assistance.

Behavior helps moderate category means students are quite able to provide assistance to others in daily life as indicated by the ability to provide psychological assistance well, but less able to provide physical assistance. The low category of helping behavior means 
that students do not provide assistance to other people in daily life, that is, they do not provide physical and psychological assistance

Achievement of cooperative behavior $70 \%$ are in the High category. High category cooperative behavior means students are able to behave cooperatively in daily life characterized by interest in working together, being fair in a group, being responsible and providing benefits to the group. Medium category cooperative behavior means students are quite capable of cooperative behavior in daily life which is characterized by the ability to benefit the group well, but is less than optimal in showing interest in working together, being fair in groups, and being responsible in groups.

Low category cooperative behavior means students have not been able to show cooperative behavior in daily life which is shown by not being interested in working together, not being fair in groups, not being responsible in groups, and not providing benefits to the group. The lowest achievement in the indicator of problem solving behavior is $63 \%$, in the medium category. High category problem solving behavior means students are able to act to solve group problems in daily life that are characterized by the ability to formulate alternative problem solving well and choose and make effective alternative problem solving.

Medium category problem solving behavior means students are quite capable of acting to solve group problems in daily life which are characterized by the ability to formulate alternative problem solving but are less than optimal in choosing and performing effective alternative problem solving. Low category problem solving behavior means students are unable to act to solve group problems in daily life that are characterized by not being able to formulate alternative problem solving well and unable to choose and make effective alternative problem solving.

\section{Implication}

Development of child pro-social behavior can be done at school. The choice of school as a place to provide services is because the school is a natural place for children. The school is a place where children spend a lot of time learning and socializing with peers, teachers and school staff. The pro-social behavior developed in research is in line with the formulation of the national education goals mentioned in the national law number 23 of 2003, which is to form the nation's character and civilization with dignity, noble and democratic character. pro-social behavior taught to students helps shape the nation's next generation into a noble person who is able to behave to benefit others. Concern and cooperative behavior in pro-social behavior also help students to learn to behave democratically from an early age.

The formation of pro-social behavior in schools is expected to be generalized and applied by students in daily life at school. The type of service performed is collaborative services with school counselors and classroom teachers. The collaborative guidance program was adapted from a model developed and applied by Warger and Rutherford (1996), and was developed and used by Allsopp, et al (2000) to develop students' prosocial behavior. Initially the collaboration method was developed by Warger and Rutherford (1996) in the realm of the family, namely collaboration between counselor and parents. Later in the article Allsopp, et al (2000) a collaborative model was developed and adapted for use in school settings. The collaborative team that implements programs to develop pro-social behavior in schools are counselors and class teachers who have more opportunities to interact with students than other teachers such as religious teachers and sports teachers. Collaboration with class teachers can also learn methods for learning the integrated pro-social development of children in the learning process in class.

The power of a collaborative approach cannot be underestimated. Collaboration as a team in the school environment ie school counselors and class teachers enables more effective planning, to help students develop and solve problems efficiently. The application of collaboration guidance programs in schools allows students to be fully involved in school, it should create opportunities for the generalization of pro-social skills that students learn. The collaborative program is implemented in the form of student learning conducted by researchers as BK students and class teachers to practice pro-social behavior skills to students.

The basis of the collaboration is in accordance with the guidelines for the implementation of KDP (Strengthening Character Education) in schools. The education unit becomes a strategic tool and supports the education ecosystem in shaping the nation's character because it has a system and infrastructure ranging from urban to rural. The organization of the KDP Movement is a coordination mechanism for all stakeholders or the education ecosystem, namely school principals, educators, education personnel, school committees, and other stakeholders. All actors form integrated networks and collaborations in accordance with their respective duties and responsibilities (Kemendikbud, 2017). Referring to the governance of the KDP movement in schools, the collaborative guidance method is designed to suit and support the implementation of the KDP movement governance in schools.

The function of the counselor in the guidance and counseling service at school as a facilitator in preparing an environment that is independent for student development (Kartadinata, 2007). pro-social behavior is one of the competencies that students need to master in accordance with the task of development in the social sphere. Counselors in research act as agents of social competence development of students especially pro-social behavior. The specific role of the counselor in collaborative guidance in the implementation of basic services is the process of providing assistance to all counselees through the preparation of structural services classically or in groups that are systematically presented. The service aims at developing long-term behavior in accordance with the stages and tasks of development. The behavior developed is pro-social behavior in accordance with the stage of pro-social moral reasoning in late childhood.

Class teachers have an interest in realizing the optimal development of students. As an educator the teacher not only transfers knowledge but also norms and values. An educator needs to have good personal social 
competence so that it can be a role model for student development. The teacher's role in collaborative guidance in accordance with KDP guidelines is to integrate KDP grades in existing subjects in the curriculum structure and Local Content subjects (Mulok) through intracuricular and co-curricular activities. In intracuricular and cocurricular activities, the teacher prepares a learning planning document in the form of a Syllabus and Learning Implementation Plan (RPP) according to their respective subjects. The main values of KDP especially pro-social behavior are integrated into subjects according to the topic at the learning session conducted by the teacher.

\section{CONCLUSION}

Pro-social behavior of the fifth-grade students of SDN 2 Lembang in 2018/2019 in the high category. Indicator analysis shows cooperative behavior and helpful behavior in the high category and problem solving behavior in the moderate category. BK teachers or counselors in primary schools do not yet exist, the implication that the packing might do is collaborative guidance between visiting counselors and class teachers

\section{REFERENCES}

[1] Ahman. (1998). Efektifitas Bermain Peran Sebagai Model Bimbingan Dalam Mengembangkan Keterampilan Sosial Anak Berkemampuan Unggul. Bandung: IKIP Bandung.
[2] Allsopp, D. H. (2000).Collaborating to Teachpro-social Skills. Intervention in School and Clinic, 35(3), 1-19.

[3] Cirelli, L. K. (2018). How Interpersonal Synchrony Facilitates Early pro-social Behavior. Current Opinion In Psychology, 20,35-39.

[4] Eisenberg, N., \& Mussen, P.H. (1989). The roots of prosocial behavior in children. United Kingdom: Cambridge University Press.

[5] Elksnin, L. K., \& Elksnin, N. (2000). Parents to Teach Their Children to Be pro-social. Journal of Intervention in school and Clinic, 36(1), 27-35.

[6] Enesco. (2013). Two and a Half-Year-Old Children are pro-social Even When Their Partners are Not. Journal of Experimental Child Psychology, 116, 186-198.

[7] Kartadinata, S. 2007. Teori Bimbingan dan Konseling. Jurnal Psikologi Pendidikan dan Bimbingan. Bandung: UPI.

[8] Ross, J. (2017). You And Me: Investigating The Role Of Self-Evaluative Emotion In Preschool pro-sociality. Journal of Experimental Child Psychology, 15(5), 67-83.

[9] Susanto, A. (2015). Bimbingan dan Konseling di Tamn Kanak-Kanak. Jakarta: Prenada Media Group.

[10] Tasimi.A \& Young.L. (2016). Memories of good deeds past: The reinforcing power of pro-social behavior in children 2016. Journal of Experimental Child Psychology, 14(7), 159-166.

[11] Warger, C. L., \& Rutherford, R. B. (1996). Social skills instruction: A collaborative Approach. Ann Arbor, MI: Exceptional Innovations.

[12] Young, M. E. (2013). Learning The Art of Helping: Buiding Block and Tecniques. Pearson Merrill: Colombus. 